\title{
Enhanced tumor retention of radioiodinated anti-epidermal growth factor receptor antibody using novel bifunctional iodination linker for radioimmunotherapy
}

\author{
EUN JUNG KIM ${ }^{1,3}$, BYOUNG SOO KIM ${ }^{1,2}$, DAN BEE CHOI ${ }^{1}$, SUNG-GIL CHI $^{3}$ and TAE HYUN CHOI ${ }^{2}$ \\ ${ }^{1}$ Korea Drug Development Platform using Radio-isotope (KDePRI), ${ }^{2}$ Department of Molecular Imaging, \\ Korea Institute of Radiological and Medical Sciences; ${ }^{3}$ School of Life Sciences and Biotechnology, \\ Korea University, Seoul, Republic of Korea
}

Received December 17, 2015; Accepted January 27, 2016

DOI: $10.3892 /$ or.2016.4706

\begin{abstract}
Radioimmunotherapy (RIT) uses an antibody labeled with a radionuclide to deliver cytotoxic radiation to a target tumor cells. Radioiodine is most commonly employed to prepare radiolabeled proteins (antibodies, peptides) for in vitro and in vivo applications. A major shortcoming of radioiodinated proteins prepared by direct labeling methods is their deiodination in vivo. For the preparation of more stable radioiodinated antibodies, we developed a new linker (N-(4isothiocyanatobenzyl)-2-(3-(tributylstannyl)phenyl) acetamide (IBPA). This study evaluated the usefulness of IBPA as a linker for the stable radioiodinated internalizing antibody, cetuximab. Directly labeled cetuximab ([ $\left.{ }^{125} \mathrm{I}\right]$-cetuximab) was prepared by the chloramine $\mathrm{T}$ method. To prepare indirectly labeled cetuximab using IBPA ([ $\left.{ }^{125} \mathrm{I}\right]-\mathrm{IBPA}-$ cetuximab), IBPA was radioiodinated using chloramine-T to give $\mathrm{N}$-(4-isothiocyanatobenzyl)-2-(3-[ $\left.{ }^{125} \mathrm{I}\right]$ phenyl)acetamide ([ $\left.\left.{ }^{125} \mathrm{I}\right]-\mathrm{IBPA}\right)$, which was purified by high performance liquid chromatography. [ ${ }^{125}$ I]-IBPA was then conjugated to cetuximab. In vitro target binding and internalizing assays were performed in PC9, LS174T, and FaDu cell lines. In vivo planar images were obtained using an Inveon SPECT scanner 3, 24, 48, and $168 \mathrm{~h}$ after i.v. injection of $\left[{ }^{125} \mathrm{I}\right]$-cetuximab or [ $\left.{ }^{125} \mathrm{I}\right]$-IBPAcetuximab in athymic mice bearing LS174T tumor xenografts. Specific binding and internalized radioactivity of $\left[{ }^{125} \mathrm{I}\right]-\mathrm{IBPA}-$ cetuximab were higher than those of $\left[{ }^{125} \mathrm{I}\right]$-cetuximab in PC9, LS174T, and FaDu cell lines. In planar images scant radioactivity was evident in thyroid glands after injection of
\end{abstract}

Correspondence to: Dr Tae Hyun Choi, Department of Molecular Imaging, Korea Institute of Radiological and Medical Sciences (KIRAMS), 75 Nowon-ro, Nowon-gu, Seoul 01812, Republic of Korea

E-mail: thchoi@kirams.re.kr

Key words: radioimmunotherapy, tumor targeting, (N-(4-isothiocyanatobenzyl)-2-(3-(tributylstannyl)phenyl) acetamide (IBPA), deiodination
[25I]-IBPA-cetuximab, while a high level of radioactivity was present in thyroid glands after injection of $\left[{ }^{125} \mathrm{I}\right]$-cetuximab. Tumor uptake value of $\left[{ }^{125} \mathrm{I}\right]$-IBPA-cetuximab was higher than that of $\left[{ }^{125} \mathrm{I}\right]$-cetuximab for up to $168 \mathrm{~h}$. [ $\left.{ }^{125} \mathrm{I}\right]$-IBPA-cetuximab is stable and resistant to deiodination in vivo. IBPA is a promising bi-functional linker for radioiodination of internalizing monoclonal antibodies for in vivo applications including radioimmunotherapy.

\section{Introduction}

About half of all newly diagnosed cancer cases are not healed by means of conventional treatment, such as surgery, chemotherapy, and radiotherapy. The major cause is the existence of residual tumor cells and metastases, which can give rise to a relapse of the primary tumor or new tumors somewhere else in the body. Metastases might consist of only a few malignant cells, and can thus avoid detection and removal. In some cases, systemic treatment with chemotherapeutics can be of some aid but the lack of specificity, in combination with an unacceptable level of general toxicity, often prevents this from being a curative treatment. It would appear that the solution should involve selective delivery of cytotoxic substances to tumor cells, thus saving the healthy tissues from damage. Access based on this reasoning is called 'tumor targeting' $(1,2)$.

Radioimmunotherapy, a therapeutic modality in which radiolabeled monoclonal antibodies (mAbs) are used to selectively target ionizing radiation to tumor cells, has principally involved the $\beta$ emitter. The radiolabel has advantages and disadvantages warranting use, possibly for different applications $(3,4)$.

Iodine-131 has been the primary radionuclide for radioimmunotherapy, in part because labeling methods are rapid, simple and high specific radioactivity of products is achievable (3). An advantage of using iodine nuclides for labeling mAbs is the availability of multiple nuclides $\left({ }^{123} \mathrm{I},{ }^{124} \mathrm{I},{ }^{125} \mathrm{I}\right.$, $\left.{ }^{131} \mathrm{I}\right)$ with useful decay characteristics (5). The direct radioiodination of Abs is well established and the most common procedure is the in situ generation of radioiodine from radioiodide by suitable oxidants such as chloramine-T and iodogen methods (6). 
Early experiments with tumor-targeting and targeted radionuclide therapy were performed using I-131 as label (7). The low price and availability of I-131 are compelling features also playing an important role, and it is currently the most widely used therapeutic nuclide (8). In addition, the highest reported response rates, complete response rates, and longest response durations reported with radioimmunoconjugates have been observed in clinical trials using I-131 as the therapeutic nuclide (9-11).

The most significant disadvantage of radioiodinated Abs is their rapid deiodination in vivo by the action of specific enzymes, probably because of the structural similarity between these iodophenyl groups and thyroid hormones (12). The decomposition of label from radioiodinated Abs is reflected by the uptake of free iodide in thyroidal glands and stomach. The catabolic product of radioiodinated $\mathrm{Ab}$, monoiodotyrosine, is able to diffuse out of target cells. This leads to shortened residence times and correspondingly lower radiation doses delivered to the tumor target $(13,14)$.

To resolve this problem, previous research developed a method that decreases the structural similarity of the labeling site on the $\mathrm{Ab}$ to these enzymatically degradable substrates by avoiding substitution of the iodine ortho to a hydroxyl group on an aromatic ring (tyrosine residue of the antibody) (12). After radioiodination and conjugation to Abs, these labeling linkers provide products with greater stability when used in vivo than the directly radioiodinated products (14).

We have designed and synthesized a new bi-functional linker for radiohalogenation of antibodies, N-(4-isothiocyanatobenzyl)-2-(3-(tributylstannyl)phenyl)acetamide(IBPA, patent no. 10-1550399KR). Isothiocyanate was introduced for structural stability both in water and most solvents. Herein we present a comparative study on evaluating usefulness of IBPA as a linker for the stable radioiodinated internalizing $\mathrm{mAb}$, cetuximab.

\section{Materials and methods}

Radioiodination of IBPA. $\mathrm{Na}^{125} \mathrm{I}$ in $0.1 \mathrm{~N} \mathrm{NaOH}$ (Perkin-Elmer, Inc., Waltham, MA, USA) was added to $100 \mu 1$ of IBPA (1 $\mathrm{mg} / \mathrm{ml}$ in dimethylsulfoxide, DMSO) and followed by $10 \mu \mathrm{l}$ of chloramine $\mathrm{T}(1 \mathrm{mg} / \mathrm{ml}$ in water). After $10-15 \mathrm{~min}$ at room temperature, the reaction was quenched with $10 \mu \mathrm{l}$ of sodium metabisulfite $(2.5 \mathrm{mg} / \mathrm{ml}$ in water). The radioiodinated compound ([$\left.\left.{ }^{125} \mathrm{I}\right]-\mathrm{IBPA}\right)$ was purified by high performance liquid chromatography (HPLC). The reaction mixture was loaded on a uBondaPak ${ }^{\mathrm{TM}} \mathrm{C}_{18}$ column $(300 \times 3.9 \mathrm{~mm}, 10 \mu \mathrm{m})$ and eluted using the linear gradient of $65-90 \%$ acetonitrile over $30 \mathrm{~min}$ with flow rate of $1.0 \mathrm{ml} / \mathrm{min}$. The eluted [ $\left.{ }^{125} \mathrm{I}\right]-\mathrm{IBPA}$ was collected and dried under a stream of nitrogen. [ $\left.{ }^{125} \mathrm{I}\right]-\mathrm{IBPA}$ was reconstructed with DMSO.

Conjugation of $\left[{ }^{125} \mathrm{I}\right]-\mathrm{IBPA}$ to cetuximab. [ $\left.{ }^{125} \mathrm{I}\right]-\mathrm{IBPA}$ was conjugated to cetuximab. Cetuximab is an $\operatorname{IgG~mAb}$ that targets the epidermal growth factor receptor (EGFR); it was purchased from Merck KGaA (Darmstadt, Germany). A portion $(200 \mu \mathrm{l})$ of cetuximab $(5 \mathrm{mg} / \mathrm{ml})$ in borate buffer (pH 8.5) was added to [ $\left.{ }^{125} \mathrm{I}\right]-\mathrm{IBPA}$. The mixture was vortexed and incubated at $37^{\circ} \mathrm{C}$ for $2 \mathrm{~h}$. Labeled $\mathrm{mAb}$ was purified by PD-10 desalting columns (GE Healthcare, Buckinghamshire,
UK) using BupH phosphate buffer ( $\mathrm{pH}$ 7.2) as an elution buffer. Radiochemical purity was measured by thin-layerchromatography (TLC) using an AR 2000 radio-TLC scanner (Eckert \& Ziegler, Berlin, Germany).

Radioiodination of cetuximab. $\left[{ }^{125} \mathrm{I}\right]$-cetuximab was prepared by direct labeling of cetuximab with iodine-125. Cetuximab $(12 \mu \mathrm{l} ; 5 \mathrm{mg} / \mathrm{ml})$ in $\mathrm{BupH}$ phosphate buffer $(\mathrm{pH}$ 7.2) was added to $\mathrm{Na}^{125} \mathrm{I}$ in $0.1 \mathrm{~N} \mathrm{NaOH}$, followed by $10 \mu \mathrm{l}$ of chloramine-T ( $1 \mathrm{mg} / \mathrm{ml}$, in BupH phosphate buffer). After standing for $20 \mathrm{sec}$ at room temperature, the reaction was terminated with $10 \mu \mathrm{l}$ of sodium metabisulfite $(2.5 \mathrm{mg} / \mathrm{ml})$. The labeled mAbs were isolated by a $\mathrm{Zeba}^{\mathrm{TM}}$ Spin desalting column, $75 \mu \mathrm{l}$ (Thermo Fisher Scientific, Waltham, MA, USA) using BupH phosphate buffer as running buffer. Radiochemical purity was measured by radio-TLC.

Stability of [ [25I]-cetuximab and [25I]-IBPA-cetuximab in mouse and human serum. To assess the stability of $\left[{ }^{125} \mathrm{I}\right]$-cetuximab and $\left[{ }^{125} \mathrm{I}\right]$-IBPA-cetuximab in mouse or human serum, $5 \mu \mathrm{l}(0.37 \mathrm{MBq})$ of $\left[{ }^{125} \mathrm{I}\right]$-cetuximab or [ $\left.{ }^{125} \mathrm{I}\right]-\mathrm{IBPA}-$ cetuximab was added to $200 \mu \mathrm{l}$ aliquots of control mouse or human serum (IRT-SER; Innovative Research, Inc., Novi, MI, USA). The mixtures were incubated in a Personal-11SD shaking water bath (TAITEC, Saitama-ken, Japan) at $37^{\circ} \mathrm{C}$ with $40 \mathrm{rpm}$ agitation. One milliliter of acetonitrile was added to the mixture and incubated for $0.5,1,2,4$ and $8 \mathrm{~h}$ ( $\mathrm{n}=3$ each) after the incubation. Samples acquired prior to acetonitrile addition and at the various times were mixed on a vortex mixer for $1 \mathrm{~min}$ and centrifuged for $10 \mathrm{~min}$ at $13,200 \mathrm{rpm}, 4^{\circ} \mathrm{C}$ in a model 5810R apparatus (Eppendorf, Hamburg, Germany). The supernatants and precipitants were separately collected. Their radioactivities were measured by a gamma counter (Perkin-Elmer, Inc.).

Stability of [ [25I]-cetuximab and [25I]-IBPA-cetuximab in mouse and human liver microsome. In order to assess the stability of $\left[{ }^{125} \mathrm{I}\right]$-cetuximab and $\left[{ }^{125} \mathrm{I}\right]$-IBPA-cetuximab in mouse or human liver microsome, $5 \mu \mathrm{l}(0.37 \mathrm{MBq})$ of $\left[{ }^{125} \mathrm{I}\right]$-rituximab and [ $\left.{ }^{125} \mathrm{I}\right]$-IBPA-cetuximab were added to $108 \mu \mathrm{l}$ of the microsomal incubation mixture. The microsomal incubation mixture consists of $0.1 \mathrm{M} \mathrm{KH}_{2} \mathrm{PO}_{4}(\mathrm{pH} 7.4,55 \mu \mathrm{l})$, $0.1 \mathrm{M} \mathrm{MgCl}_{2}(10 \mu \mathrm{l})$, and $20 \mu \mathrm{l}$ of $5 \mathrm{mg} / \mathrm{ml}$ mouse or human liver microsome pooled (BD Gentest, San Jose, CA, USA). After pre-incubation of the mixture for $3 \mathrm{~min}$ in a shaking water bath at $37^{\circ} \mathrm{C}$ with $40 \mathrm{rpm}$ agitation, the reaction was initiated by adding $10 \mu \mathrm{l}$ of $10 \mathrm{mM}$ NADPH. Adding $1 \mathrm{ml}$ of acetonitrile to the mixture, the reaction was terminated prior to and 5,10 , and $30 \mathrm{~min}(\mathrm{n}=3$ each) after the incubation. The samples were mixed on a vortex mixer for $1 \mathrm{~min}$ and centrifuged for $10 \mathrm{~min}$ at $13,200 \mathrm{rpm}, 4^{\circ} \mathrm{C}$. The supernatants were transferred to a glass tube. Their radioactivity was counted with a gamma counter (Perkin-Elmer, Inc.).

Cell lines and cultures. LS174T human colon cancer, PC9 human lung cancer, and $\mathrm{FaDu}$ squamous cell carcinoma cell lines, which all overexpress epidermal growth factor receptor, were purchased from the American Type Culture Collection (ATCC, Manassas, VA, USA). All cells were grown in Hyclone $^{\mathrm{TM}}$ DMEM (Thermo Fisher Scientific) supplemented 
with $10 \%$ fetal bovine serum (FBS; JR Scientific, Woodland, CA, USA) and $1 \%$ antibiotics (Thermo Fisher Scientific). The medium was changed twice or three times per week. The cells were cultured at $37^{\circ} \mathrm{C}$ in a $5 \% \mathrm{CO}_{2}$ atmosphere.

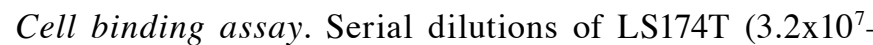
$0.25 \times 10^{6}$ cells $)$, PC9 $\left(0.8 \times 10^{7}-0.06 \times 10^{6}\right.$ cells $)$, and $\mathrm{FaDu}$ $\left(0.4 \times 10^{7}-0.06 \times 10^{6}\right.$ cells $)$ cells in $1 \%$ bovine serum albumin (BSA) in phosphate buffered saline (PBS) were incubated with $\left.{ }^{[25} \mathrm{I}\right]$-cetuximab or $\left.{ }^{125} \mathrm{I}\right]$-IBPA-cetuximab $(<0.004 \mathrm{MBq})$ for $1 \mathrm{~h}$ at $4^{\circ} \mathrm{C}(\mathrm{n}=3)$. The cells were centrifuged and washed twice with casein blocking buffer (1\% casein in PBS). The radioactivity bound to the cells was counted with a Wizard gamma counter (Perkin-Elmer, Inc.). The immunoreactivity of radiolabeled $\mathrm{Ab}$ was estimated as described previously (15).

Internalization assay. For internalization assays, LS174T cells were harvested and seeded on 6-well plates $(100,000$ 300,000 cells $/$ well, $1 \mathrm{ml}$ ). After overnight incubation, $1 \mu \mathrm{g}$ of radiolabeled $\mathrm{Ab}(0.07 \mathrm{MBq})$ in $10 \mu \mathrm{l}$ was added to each well and incubated for 1,4 , and $24 \mathrm{~h}$ at $37^{\circ} \mathrm{C}(\mathrm{n}=3)$. Then medium was removed and the cells were gently washed with ice-cold PBS followed by the addition of ice-cold acidic stripping buffer $(1 \mathrm{ml})$ and $1 \mathrm{M} \mathrm{NaOH}(500 \mu \mathrm{l})$. Radioactivity of the cell culture medium, acid washes (cell surface bound), and the cell lysates (internalized) was counted using the aforementioned gamma counter. The ratio of internal $\mathrm{cpm} /$ total bound $\mathrm{cpm}$, $\%$ surface binding, and \% internal binding to total activity were calculated using the equations below:

Internal/total bound $=\mathrm{cpm}$ of acid wash/cpm of (acid wash + cell lysate) [1]

$\%$ surface bound $=100 \mathrm{x} \mathrm{cpm}$ of acid wash $/ \mathrm{cpm}$ of (media + acid wash + cell lysate) [2]

$\%$ internalized $=100 \mathrm{x} \mathrm{cpm}$ of cell lysate/cpm of (media + acid wash + cell lysate) [3]

Tumor xenograft model. All animal experiments were approved by the pertinent committee of KIRAMS and were performed in compliance with institutional guidelines for conducting animal experiments. Five-to-six-week-old female BALB/c nu/nu mice (Central Lab. Animal, Seoul, Korea) were used for the establishment of a tumor model. LS174T cells $\left(1 \times 10^{6}\right.$ cells) suspended in $100 \mathrm{ml}$ of serum-free cell culture medium were subcutaneously transplanted into the right leg of each mouse. Tumor growth was assessed by measuring the bidimensional diameters using calipers. Mice bearing subcutaneous tumors with a volume reaching $\sim 1,000 \mathrm{~mm}^{3}$ were used for in vivo experiments.

Planar images of radiolabled mAbs in nude mice bearing subcutaneous LS174T tumor xenografts. For the imaging study, mice were anesthetized by isoflurane $/ \mathrm{N}_{2} \mathrm{O} / \mathrm{O}_{2}$ inhalation anesthesia. After the injection of $\left.{ }^{[25} \mathrm{I}\right]$-cetuximab or $\left[{ }^{125} \mathrm{I}\right]$-IBPA-cetuximab (3.8-6.0 MBq) via the tail vein, static images of each mouse were obtained at 3,24, 48, and $168 \mathrm{~h}$ using an Inveon SPECT scanner (Siemens Preclinical Solutions, Malvern, PA, USA) equipped with a low energy all-purpose collimator. The images were acquired until 100,000 counts per total body image. Image analysis was performed by quantifi- cation of $\left[{ }^{125} \mathrm{I}\right]$ retention in the region of interest (ROI) of the body, thyroid, and tumor using image analysis software.

Biodistribution of radiolabled $m A b s$ in nude mice bearing subcutaneous LS174T tumor xenografts. Biodistribution studies of $\left[{ }^{125} \mathrm{I}\right]$-cetuximab or $\left[{ }^{125} \mathrm{I}\right]$-IBPA-cetuximab were AMIDE performed in nude mice bearing subcutaneous LS174T tumor xenografts. Animals were injected with $\left[{ }^{125} \mathrm{I}\right]$-cetuximab or [ $\left.{ }^{125} \mathrm{I}\right]-$-IBPA-cetuximab $(0.1 \mathrm{MBq})$ via the tail vein and sacrificed at $48 \mathrm{~h}$ post-injection $(\mathrm{n}=6)$. Blood and organs were excised and weighed, and their radioactivities were measured using the gamma counter.

Pharmacokinetics in nude mice bearing subcutaneous LS174T tumor xenografts. $\left[{ }^{125} \mathrm{I}\right]$-cetuximab or [ $\left[{ }^{125} \mathrm{I}\right]-\mathrm{IBPA}-$ cetuximab $(0.74 \mathrm{MBq})$ was injected via the tail vein in nude mice bearing subcutaneous LS174T tumor xenografts. Blood samples were collected in each group $(n=5)$ at 2, 4, 8, 24, 48, $72,168,336$, and $504 \mathrm{~h}$. Plasma was separated by centrifugation at 13,200 rpm for $5 \mathrm{~min}$ using a model 5415R apparatus (Eppendorf). Plasma samples $(10 \mu \mathrm{l})$ were immediately mixed with acetonitrile solution $(100 \mu \mathrm{l})$. The samples were centrifuged at $4^{\circ} \mathrm{C}$ for $10 \mathrm{~min}$ at $13,200 \mathrm{rpm}$. Radioactivity in the precipitant and supernatant were counted using the gamma counter. The pharmacokinetic parameters were estimated by a non-compartmental method using WinNolin ver 2.0 software (Pharsight Corp., Cary, NC, USA).

\section{Results}

Radioiodination. $\left[{ }^{125} \mathrm{I}\right]$-IBPA was prepared by the chloramine-T method and purified by preparation HPLC. The average radioiodination yield of IBPA was $79.70 \pm 3.56 \%$ $(\mathrm{n}=5)$. A representative HPLC chromatogram is shown in Fig. 1. Radiolabeling yield of [ $\left.{ }^{125} \mathrm{I}\right]$-cetuximab and $\left[{ }^{125} \mathrm{I}\right]-\mathrm{IBPA}-$ cetuximab was $53.60 \pm 6.17$ and $40.83 \pm 4.48 \%(n=5)$, respectively. Radiochemical purities of $\left[{ }^{125} \mathrm{I}\right]$-cetuximab and [25I]-IBPA-cetuximab exceeded $98 \%$.

Stability of $\left[{ }^{125} I\right]$-cetuximab and $\left[{ }^{125} I\right]-I B P A$-cetuximab in mouse and human serum. The mean percentage amount of $\left[{ }^{125} \mathrm{I}\right]$-cetuximab and $\left.{ }^{[25} \mathrm{I}\right]-\mathrm{IBPA}$-cetuximab remaining with time after the incubation of $\left[{ }^{125} \mathrm{I}\right]$-cetuximab and $\left[{ }^{125} \mathrm{I}\right]-\mathrm{IBPA}-$ cetuximab in mouse and human serum are shown in Fig. 2. $\left[{ }^{125} \mathrm{I}\right]$-cetuximab and $\left[{ }^{125} \mathrm{I}\right]$-IBPA-cetuximab were stable in mouse and human serum. The percentages of $\left[{ }^{125} \mathrm{I}\right]$-cetuximab and $\left[{ }^{125} \mathrm{I}\right]$-IBPA-cetuximab remaining at $0,0.5,1,2,4$, and $8 \mathrm{~h}$ after incubation in mouse serum exceeded $94 \%$. The percentages of $\left[{ }^{125} \mathrm{I}\right]$-cetuximab and $\left[{ }^{125} \mathrm{I}\right]-$ IBPA-cetuximab remaining at $0,0.5,1,2,4$, and $8 \mathrm{~h}$ after incubation in human serum exceeded $91 \%$.

Stability of [ $\left.{ }^{125} I\right]$-cetuximab and [125I]-IBPA-cetuximab in mouse and human liver microsomes. The mean percentage amount of $\left[{ }^{125} \mathrm{I}\right]$-cetuximab and $\left[{ }^{125} \mathrm{I}\right]$-IBPA-cetuximab remaining with time after the incubation of $\left[{ }^{[25} \mathrm{I}\right]$-cetuximab and $\left.{ }^{[25} \mathrm{I}\right]-$ IBPA-cetuximab in mouse and human liver microsomes are shown in Fig. 3. $\left[{ }^{[25} \mathrm{I}\right]$-cetuximab and $\left[{ }^{[25} \mathrm{I}\right]$-IBPA-cetuximab were stable in mouse and human liver microsomes. The percentages of $\left[{ }^{125} \mathrm{I}\right]$-cetuximab and $\left[{ }^{125} \mathrm{I}\right]$-IBPA-cetuximab 


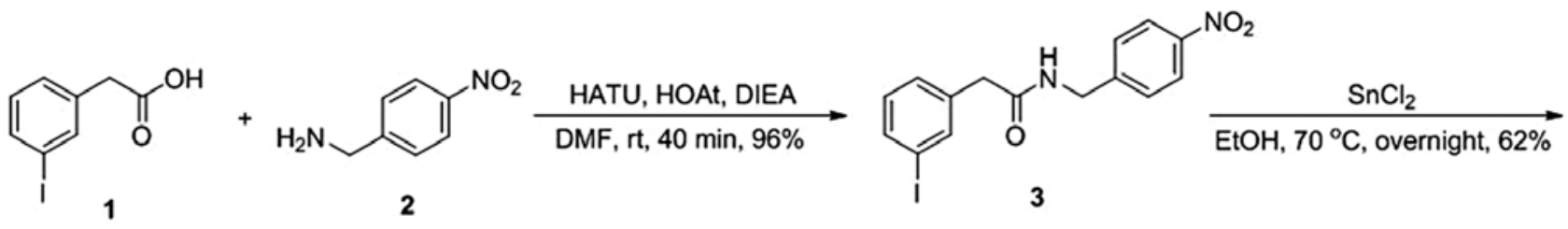<smiles>Nc1ccc(CNC(=O)Cc2cccc(I)c2)cc1</smiles><smiles>CC(C)COC(C)C</smiles>

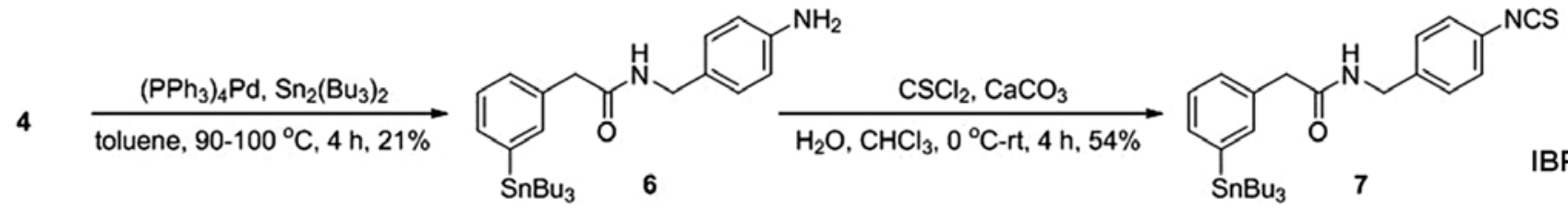

Figure 1. Synthetic scheme for the preparation of IBPA and iodo-IBPA.

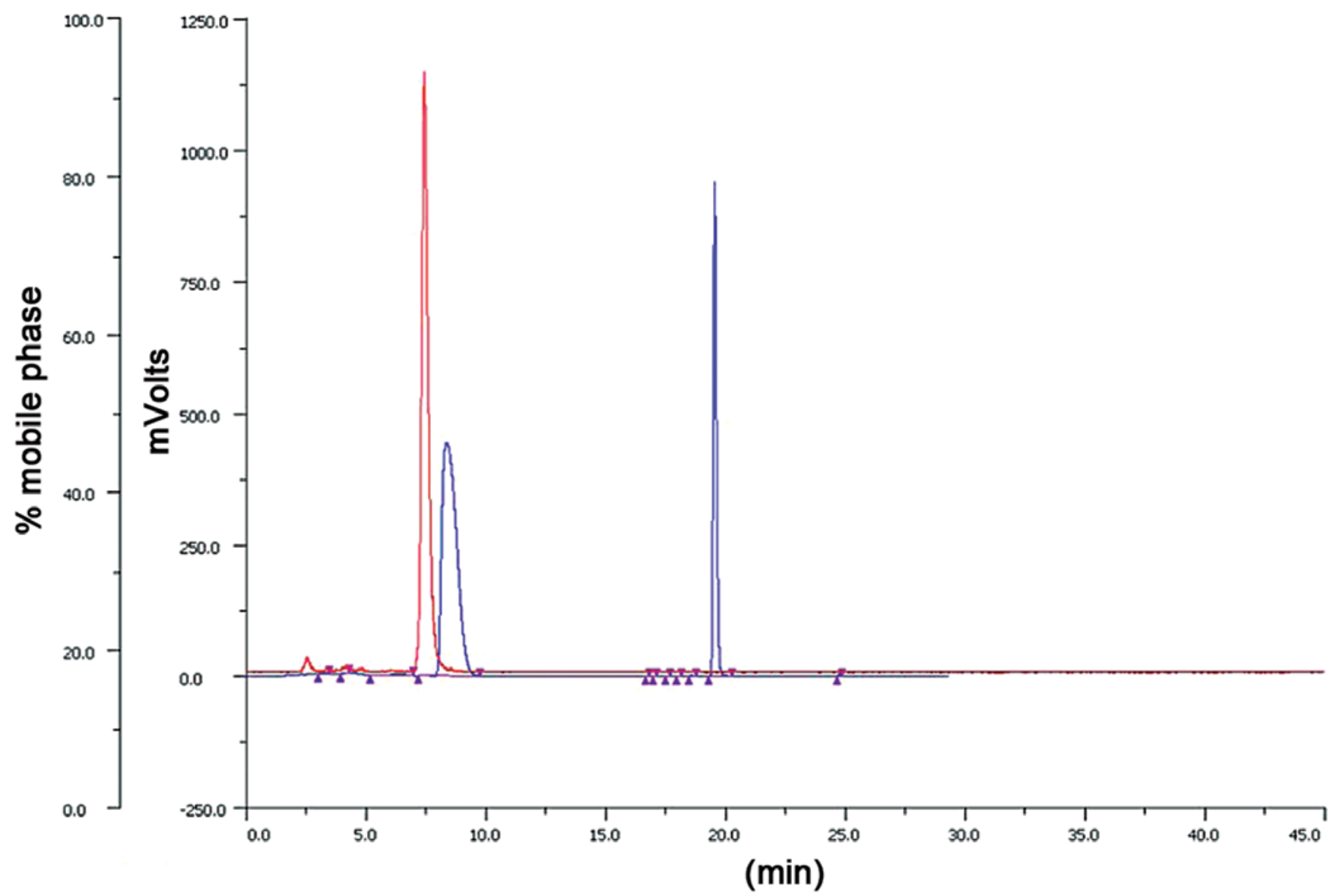

Figure 2. Radio-HPLC chromatogram of N-(4-isothiocyanatobenzyl)-2-(3-(tributylstannyl)phenyl) acetamide (IBPA) precursor (blue line, 19.8 min), N-(4isothiocyanatobenzyl)-2-(3-iodophenyl) acetamide (iodo-IBPA) authentic (blue line, $8.7 \mathrm{~min}$ ), and directly reactant $\mathrm{N}$-(4-isothiocyanatobenzyl)-2-(3-[ $\left.\left.{ }^{125} \mathrm{I}\right] \mathrm{phenyl}\right)$ acetamide ([ $\left.{ }^{125} \mathrm{I}\right]$-IBPA). The radiolabeled precursor ([ $\left.\left.{ }^{125} \mathrm{I}\right]-\mathrm{IBPA}\right)$ was collected at 7.1 to $8.5 \mathrm{~min}$ (red line). 
Mouse serum

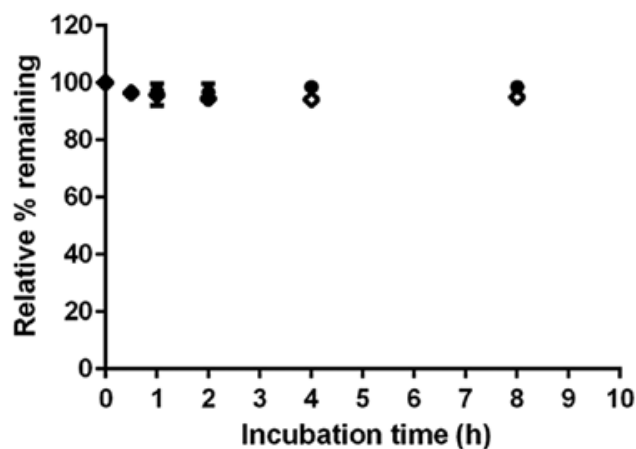

Mouse liver microsome

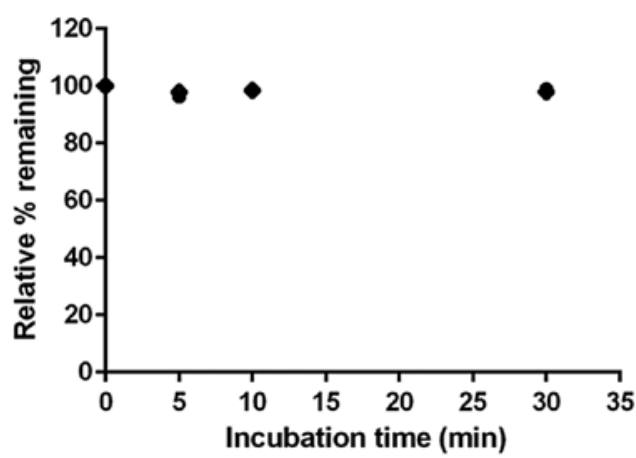

[ $\left[{ }^{125} \mathrm{I}\right]$-cetuximab

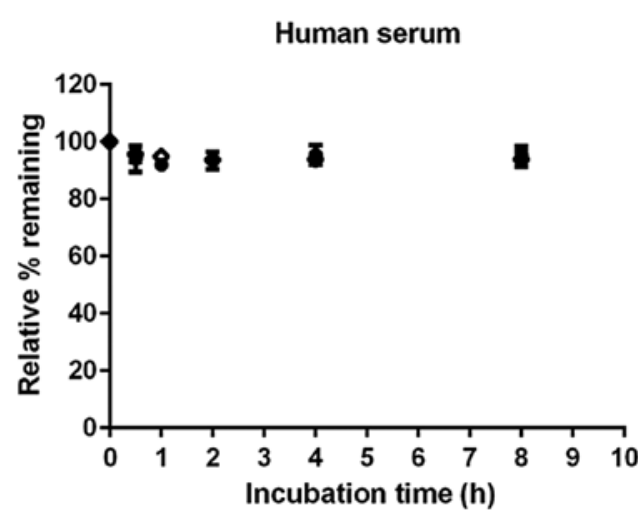

Human liver microsome

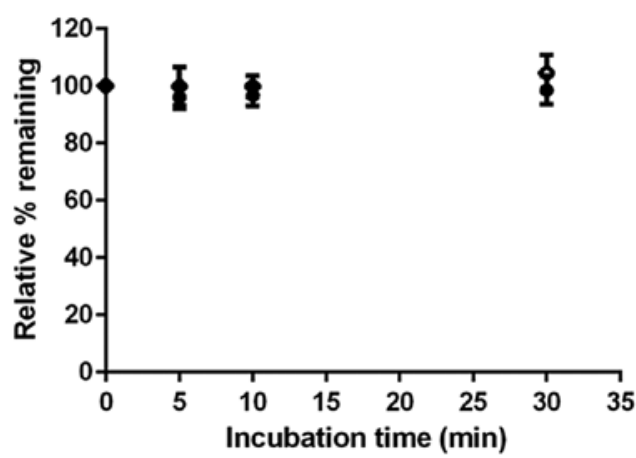

[125]]-IBPA-cetuximab

Figure 3. Average percentage amounts of [ $\left.{ }^{125} \mathrm{I}\right]$-cetuximab $(\bullet)$ and $\left[{ }^{125} \mathrm{I}\right]$-IBPA-cetuximab $(\diamond)$ remaining as a function of time during incubation in mouse serum, human serum, mouse liver microsome and human liver microsome. The data are presented as the mean \pm SD.

Table I. Internalization assay of $\left[{ }^{125} \mathrm{I}\right]$-cetuximab and $\left[{ }^{125} \mathrm{I}\right]$-IBPA-cetuximab at $37^{\circ} \mathrm{C}$ for $\leq 24 \mathrm{~h}$ in $\mathrm{LS} 174 \mathrm{~T}$, PC9 and FaDu cell lines.

\begin{tabular}{|c|c|c|c|c|c|}
\hline \multirow[b]{2}{*}{ Cell line } & \multirow[b]{2}{*}{ Time $(\mathrm{h})$} & \multicolumn{2}{|c|}{$\left[{ }^{125} \mathrm{I}\right]$-cetuximab } & \multicolumn{2}{|c|}{$\left[{ }^{125} \mathrm{I}\right]-$-IBPA-cetuximab } \\
\hline & & $\%$ Surface bound & $\%$ Internalized & $\%$ Surface bound & $\%$ Internalized \\
\hline \multirow[t]{3}{*}{ LS174T } & 1 & $0.51 \pm 0.00$ & $0.20 \pm 0.00$ & $1.30 \pm 0.03$ & $0.51 \pm 0.01$ \\
\hline & 4 & $0.56 \pm 0.01$ & $0.21 \pm 0.00$ & $1.77 \pm 0.02$ & $0.73 \pm 0.01$ \\
\hline & 24 & $0.97 \pm 0.02$ & $0.40 \pm 0.01$ & $4.08 \pm 0.03$ & $1.85 \pm 0.01$ \\
\hline \multirow[t]{3}{*}{ PC9 } & 1 & $1.41 \pm 0.02$ & $0.65 \pm 0.03$ & $3.43 \pm 0.02$ & $1.46 \pm 0.04$ \\
\hline & 4 & $1.47 \pm 0.02$ & $0.64 \pm 0.01$ & $4.03 \pm 0.05$ & $1.79 \pm 0.04$ \\
\hline & 24 & $1.53 \pm 0.04$ & $0.63 \pm 0.04$ & $5.77 \pm 0.03$ & $2.73 \pm 0.04$ \\
\hline \multirow[t]{3}{*}{$\mathrm{FaDu}$} & 1 & $0.14 \pm 0.00$ & $0.07 \pm 0.00$ & $3.74 \pm 0.02$ & $1.13 \pm 0.04$ \\
\hline & 4 & $0.19 \pm 0.00$ & $0.06 \pm 0.00$ & $4.25 \pm 0.02$ & $1.18 \pm 0.03$ \\
\hline & 24 & $0.34 \pm 0.01$ & $0.14 \pm 0.00$ & $7.62 \pm 0.11$ & $3.05 \pm 0.02$ \\
\hline
\end{tabular}

remaining at 5, 10, and 30 min after incubation in mouse and human liver microsomes exceeded $96 \%$.

Cell binding assay. An immunoreactivity assay (15) was used to determine the immunoreactive fraction of $\left[{ }^{125} \mathrm{I}\right]$-cetuximab and $\left[{ }^{125} \mathrm{I}\right]$-IBPA-cetuximab. The immunoreactive fraction value of $\left[{ }^{125} \mathrm{I}\right]$-cetuximab vs $\left[{ }^{125} \mathrm{I}\right]$-IBPA-cetuximab were 0.451 vs $0.715,0.492$ vs $0.752,0.384$ vs 0.629 in PC9, LS174T, and FaDu cells, respectively.

Internalization assay. The results of the in vitro internalization assay are shown in Table I. At $24 \mathrm{~h}$, the percentage of 

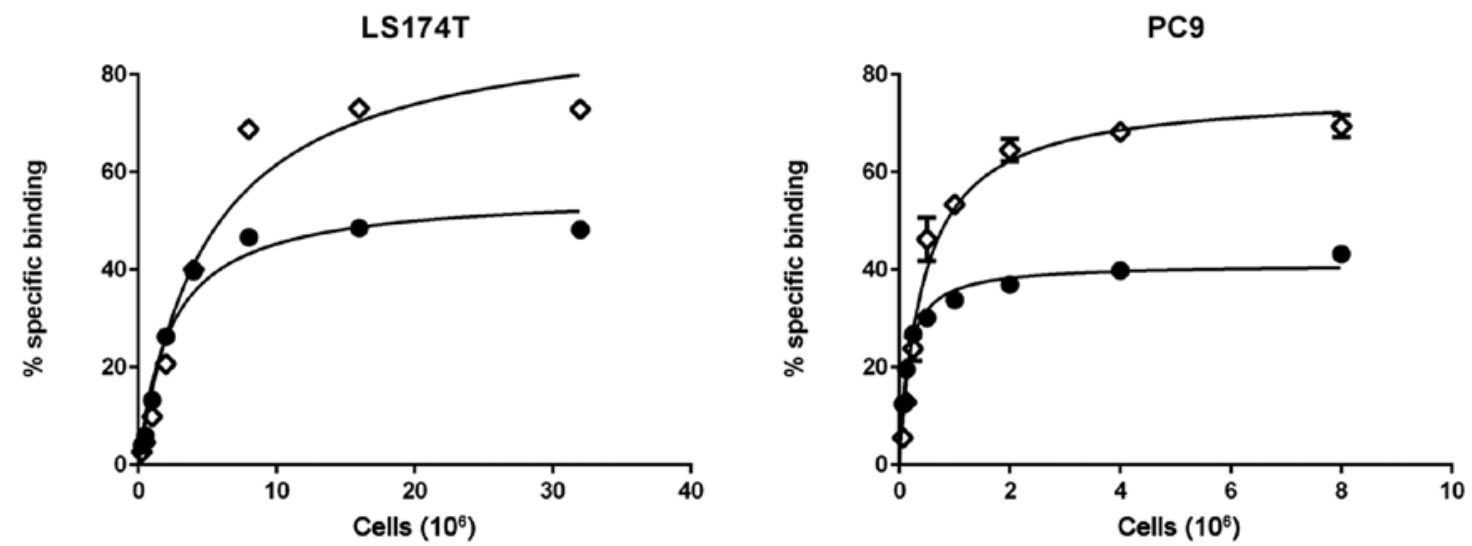

$\mathrm{FaDu}$

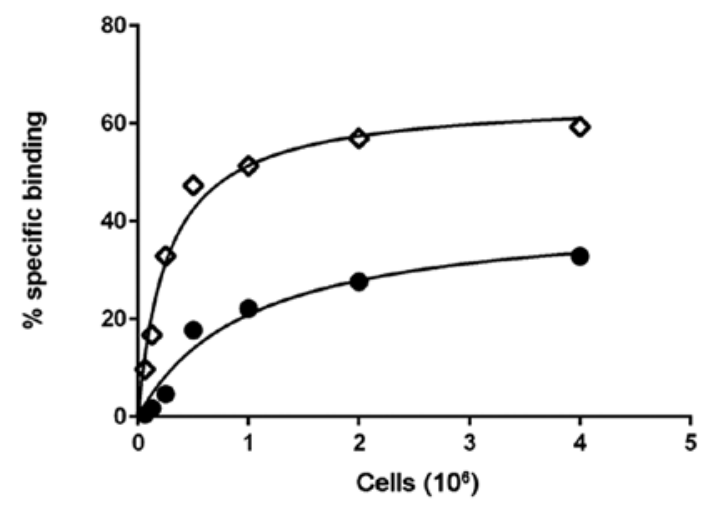

[ $\left[{ }^{125} \mid\right]$-cetuximab

[125I]-IBPA-cetuximab

Figure 4. Lindmo binding assay for the determination of the immunoreactive fraction of $\left[{ }^{125} \mathrm{I}\right]$-cetuximab $(\bullet)$ and $\left[{ }^{125} \mathrm{I}\right]-\mathrm{IBPA}$-cetuximab $(\diamond)$ in LS174T, PC9 and $\mathrm{FaDu}$ cell lines. Conventional plot of specific binding over total applied radioactivity as a function of cell concentration. The final concentration of $\left[{ }^{125} \mathrm{I}\right]$-cetuximab and $\left[{ }^{125} \mathrm{I}\right]-\mathrm{IBPA}-$ cetuximab were $30-40 \mathrm{ng} / \mathrm{ml}$. By extrapolating a fitted straight line to its intercept with the ordinate, the fraction of immunoreactive antibody is determined as the inverse of the intercept value. The data are presented as the mean $\pm \mathrm{SD}$.

surface bound per total added activity of $\left[{ }^{125} \mathrm{I}\right]$-cetuximab in PC9, LS174T, and FaDu cells was $1.53 \pm 0.04,0.97 \pm 0.02$, and $0.34 \pm 0.01 \%$, respectively, and that of $\left[{ }^{125} \mathrm{I}\right]-\mathrm{IBPA}$-cetuximab in PC9, LS174T, and FaDu cell lines was 5.77 $\pm 0.03,4.08 \pm 0.03$, and $7.62 \pm 0.11 \%$, respectively. The percentage of internalized activity of $\left[{ }^{125} \mathrm{I}\right]$-cetuximab in PC9, LS174T, and FaDu cell lines was $0.63 \pm 0.04,0.40 \pm 0.01$, and $0.14 \pm 0.00 \%$, respectively, and that of $\left[{ }^{125} \mathrm{I}\right]-\mathrm{IBPA}$-cetuximab in PC9, LS174T, and FaDu cell lines was $2.73 \pm 0.04,1.85 \pm 0.01$, and $3.05 \pm 0.02 \%$, respectively. The ratio of internalized $\mathrm{Ab}$ to total bound $\mathrm{Ab}$ was $0.4-0.5$ in both $\left[{ }^{125} \mathrm{I}\right]$-cetuximab and $\left[{ }^{125} \mathrm{I}\right]$-IBPA-cetuximab for $\leq 24 \mathrm{~h}$.

In planar images of [225I]-cetuximab and [225I]-IBPAcetuximab in nude mice bearing subcutaneous LS174T tumor xenografts. The planar images acquired after injection of $\left[{ }^{125} \mathrm{I}\right]$-cetuximab or $\left.{ }^{[25} \mathrm{I}\right]$-IBPA-cetuximab are shown in Fig. 4. In planar images of nude mice bearing subcutaneous LS174T tumor xenografts, a high level of radioactivity was detected in thyroid glands after injection of $\left[{ }^{125} \mathrm{I}\right]$-cetuximab, with little radioactivity detected in thyroid glands after injection of [ $\left.{ }^{125} \mathrm{I}\right]$-IBPA-cetuximab at 3, 24, 48, and $168 \mathrm{~h}$ post-injection. The uptake of $\left.{ }^{125} \mathrm{I}\right]-\mathrm{IBPA}$-cetuximab in the LS174T tumor region was higher than that of $\left[{ }^{125} \mathrm{I}\right]$-cetuximab. At the LS174T tumor region, accumulation of $\left[{ }^{125} \mathrm{I}\right]-\mathrm{IBPA}-\mathrm{cetuximab}$ was continuously increased up to $168 \mathrm{~h}$ post-injection. In the thyroid region, cpm of [125I]-IBPA-cetuximab $(6,153.38 \pm 257.34)$ was $\sim 3$-fold lower than that of [ $\left.{ }^{125} \mathrm{I}\right]$-cetuximab $(16,862.35 \pm 873.98)$ at $48 \mathrm{~h}$ post-injection $(\mathrm{P}<0.005)$. In the tumor region, cpm of [ $\left.{ }^{125} \mathrm{I}\right]$-IBPA-cetuximab $(32,096.75 \pm 1,533.48)$ was $\sim 2$-fold higher than that of $\left[{ }^{125} \mathrm{I}\right]$-cetuximab $(16,421.24 \pm 239.52)$ at $48 \mathrm{~h}$ post-injection $(\mathrm{P}<0.005)$.

Biodistribution of $\left[{ }^{125} I\right]$-cetuximab and $\left[{ }^{125} I\right]-I B P A-c e t u x i m a b$ in nude mice bearing subcutaneous LS174T tumor xenografts. Biodistribution profiles of radioactivity after single intravenous injection of $\left[{ }^{125} \mathrm{I}\right]$-cetuximab or $\left[{ }^{125} \mathrm{I}\right]$-IBPA-cetuximab in nude mice at a dose of 25-55 $\mu \mathrm{g} / \mathrm{each}$ are shown in Fig. 5. Radioactivity uptake in thyroid glands was obviously decreased by injection of [ ${ }^{125}$ I]-IBPA-cetuximab instead of $\left[{ }^{125} \mathrm{I}\right]$-cetuximab. The thyroidal uptake value (\%ID) after injection of [ $\left.{ }^{125} \mathrm{I}\right]-\mathrm{IBPA}$-cetuximab $(0.09 \pm 0.05)$ was $\sim 8$-fold lower than that after injection of $\left[{ }^{125} \mathrm{I}\right]$-cetuximab $(0.69 \pm 0.36)$ with a statistically significant difference $(\mathrm{P}<0.005)$. The tumor uptake value (\% ID/g) after injection of [ $\left.{ }^{125} \mathrm{I}\right]$-IBPA-cetuximab $(12.42 \pm 1.63)$ was $\sim 2$-fold higher than that after injection of $\left[{ }^{125} \mathrm{I}\right]$-cetuximab $(7.10 \pm 1.54)(\mathrm{P}<0.0005)$. The tumor/normal tissue ratio was considerably higher in [ $\left.{ }^{125} \mathrm{I}\right]$-IBPA-cetuximab than $\left[{ }^{125} \mathrm{I}\right]$-cetuximab (Table II). 


\section{A}

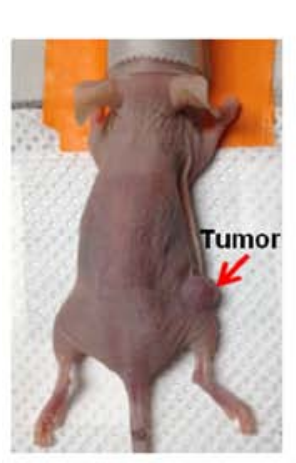

B

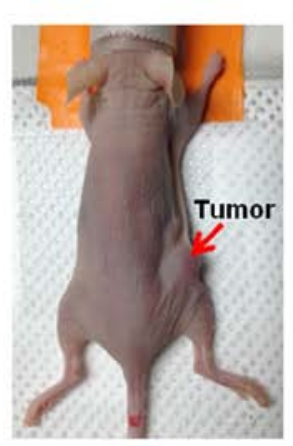

[125l]-cetuximab

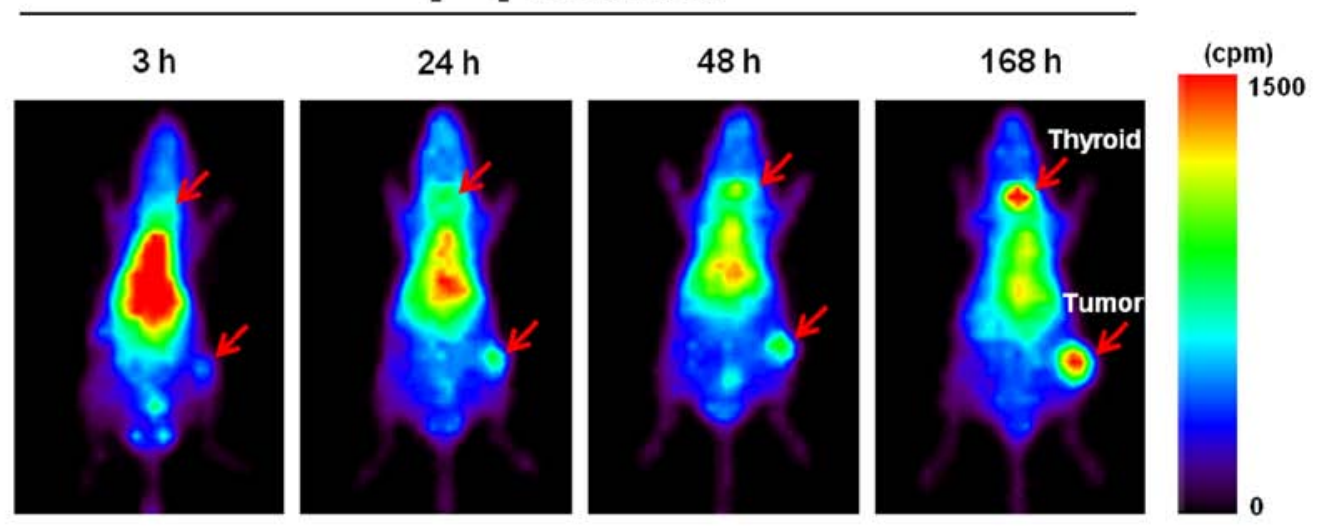

[125]]-IBPA-cetuximab
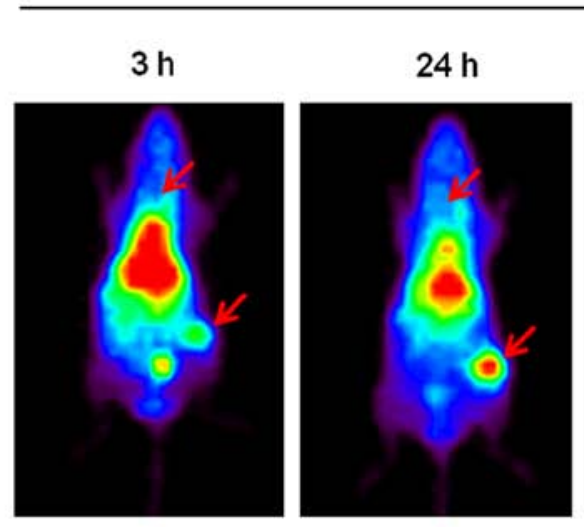
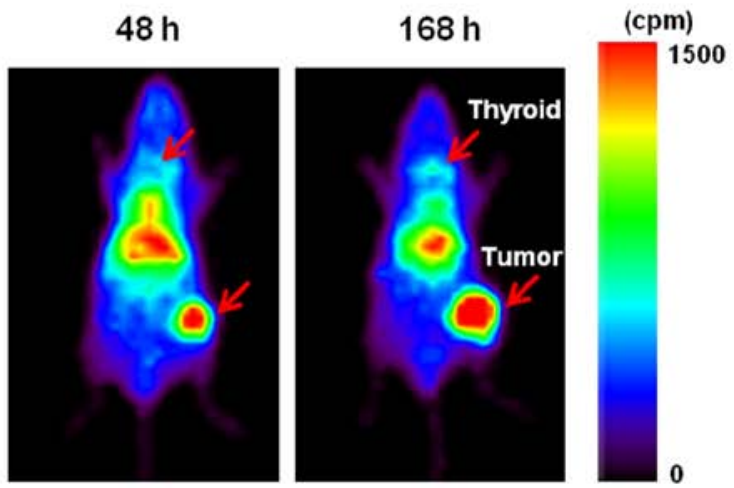

Figure 5. In planar images of (A) $\left[{ }^{125} \mathrm{I}\right]$-cetuximab and (B) $\left[{ }^{125} \mathrm{I}\right]$-IBPA-cetuximab in nude mice with LS174T xenografts. Animals were anesthetized by isoflurane $/ \mathrm{N}_{2} \mathrm{O} / \mathrm{O}_{2}$ inhalation anesthesia. The image acquisition was performed at 100,000 counts per total body image. Images were acquired at $3,24,48$, and $168 \mathrm{~h}$ after injection of $\left[{ }^{125} \mathrm{I}\right]$-cetuximab (dose $\left.27 \mu \mathrm{g} / 107 \mu \mathrm{Ci} / \mathrm{each}, \mathrm{n}=2\right)$ and $\left[{ }^{125} \mathrm{I}\right]$-IBPA-cetuximab $(\mathrm{dose} 31 \mu \mathrm{g} / 104 \mu \mathrm{Ci} / \mathrm{each}, \mathrm{n}=2)$.

Table II. Tumor to normal tissue ratios of $\left[{ }^{125} \mathrm{I}\right]$-cetuximab and $\left.{ }^{125} \mathrm{I}\right]$-IBPA-cetuximab obtained at $48 \mathrm{~h}$ after single i.v. injection in nude mice bearing LS174T xenografts.

\begin{tabular}{lcc}
\hline & {$\left[{ }^{125} \mathrm{I}\right]$-cetuximab } & {$\left[{ }^{125} \mathrm{I}\right]$-IBPA-cetuximab } \\
\hline Tumor/blood & $0.66 \pm 0.13$ & $1.48 \pm 0.36$ \\
Tumor/liver & $1.64 \pm 0.15$ & $2.23 \pm 0.39$ \\
Tumor/spleen & $3.00 \pm 0.54$ & $5.27 \pm 1.96$ \\
Tumor/kidney & $2.69 \pm 0.52$ & $4.54 \pm 1.52$ \\
Tumor/lung & $1.47 \pm 0.38$ & $2.94 \pm 1.04$ \\
Tumor/stomach & $3.79 \pm 0.85$ & $11.58 \pm 3.64$ \\
Tumor/intestine & $7.33 \pm 1.34$ & $11.32 \pm 2.34$ \\
Tumor/muscle & $3.79 \pm 0.88$ & $8.75 \pm 2.80$ \\
Tumor/femur & $4.58 \pm 1.04$ & $11.90 \pm 3.04$ \\
\hline
\end{tabular}

Values are presented as mean $\pm \mathrm{SD}$.

Pharmacokinetics of $\left[{ }^{125} I\right]$-cetuximab and [ $\left.{ }^{125} I\right]-I B P A-$ cetuximab in nude mice bearing subcutaneous LS174T tumor xenografts. The mean plasma concentrations vs. time profiles
Table III. Pharmacokinetic parameters based on the mean plasma radioactivity obtained in nude mice bearing subcutaneous LS174T xenograft models after single i.v. injection of $\left[{ }^{125} \mathrm{I}\right]$-cetuximab and $\left[{ }^{125} \mathrm{I}\right]$-IBPA-cetuximab.

Parameters $\left[{ }^{125} \mathrm{I}\right]$-cetuximab [ $\left.{ }^{125} \mathrm{I}\right]$-IBPA-cetuximab P-value

\begin{tabular}{lccc}
\hline $\mathrm{C}_{0}$ & $65.7 \pm 19.4$ & $69.6 \pm 13.1$ & 0.602 \\
$(\% \mathrm{ID} / \mathrm{ml})$ & & & \\
$\mathrm{t}_{1 / 2}, \lambda_{\mathrm{z}}(\mathrm{h})$ & $91.0 \pm 8.0$ & $73.8 \pm 4.8$ & 0.003 \\
$\mathrm{AUC}_{\mathrm{inf}}$ & $4,069.6 \pm 601.0$ & $2,964.5 \pm 707.0$ & 0.029 \\
$\left(\% \mathrm{ID}{ }^{*} \mathrm{~h} / \mathrm{ml}\right)$ & & & \\
$\mathrm{Vz}(\mathrm{ml})$ & $3.3 \pm 0.7$ & $3.7 \pm 0.8$ & 0.410 \\
$\mathrm{Cl}(\mathrm{ml} / \mathrm{h})$ & $0.025 \pm 0.004$ & $0.035 \pm 0.008$ & 0.027 \\
\hline
\end{tabular}

i.v., intravenous; $\mathrm{C}_{0}$, blood concentration extrapolated to time zero; $\mathrm{t}_{1 / 2}, \lambda_{\mathrm{z}}$, terminal half-life; $\mathrm{AUC}_{\text {inf, }}$ area under plasma concentrationtime curve to infinite time; $\mathrm{V}_{\mathrm{z}}$, volume of distribution; $\mathrm{Cl}$, clearance.

after i.v. injection of $\left[{ }^{125} \mathrm{I}\right]$-cetuximab or $\left[{ }^{[25} \mathrm{I}\right]$-IBPA-cetuximab are shown in Fig. 6. Individual plasma concentrations vs. time profiles were analyzed according to non-compartmental 

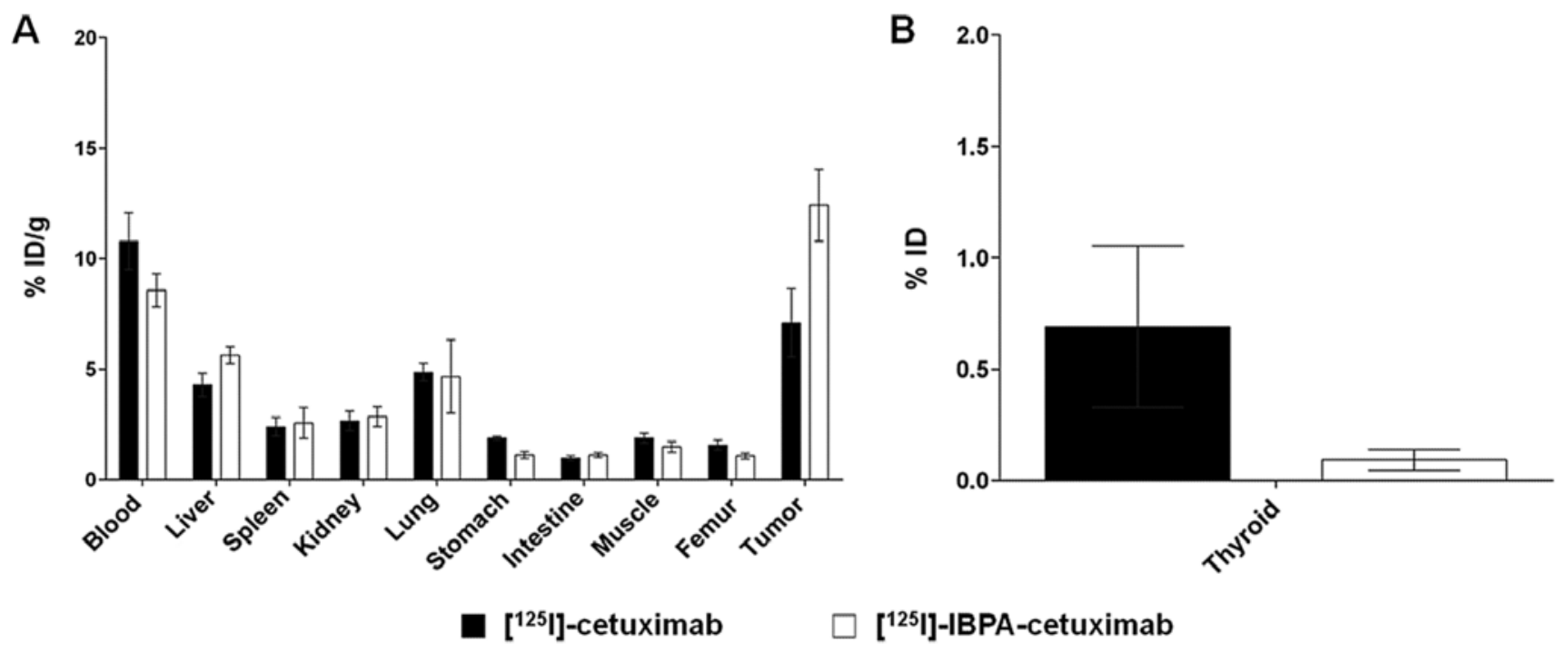

Figure 6. Biodistribution of [ $\left.{ }^{125} \mathrm{I}\right]$-cetuximab ( $\mathbf{\square}$, dose $31.1 \mu \mathrm{g} / 2.6 \mu \mathrm{Ci} /$ each) and $\left[{ }^{125} \mathrm{I}\right]-\mathrm{IBPA}$-cetuximab ( $\square$, dose $27.8 \mu \mathrm{g} / 2.5 \mu \mathrm{Ci} /$ each) obtained $48 \mathrm{~h}$ after single i.v. injection in nude mice bearing LS174T xenografts. (A) Values are presented as mean \% ID/g \pm SD (n=6 each bar). \% ID/g, percent injected dose per gram of tissue. (B) Values are presented as mean \% ID \pm SD ( $n=6$ each bar). \% ID, percent injected dose per gram of thyroid.

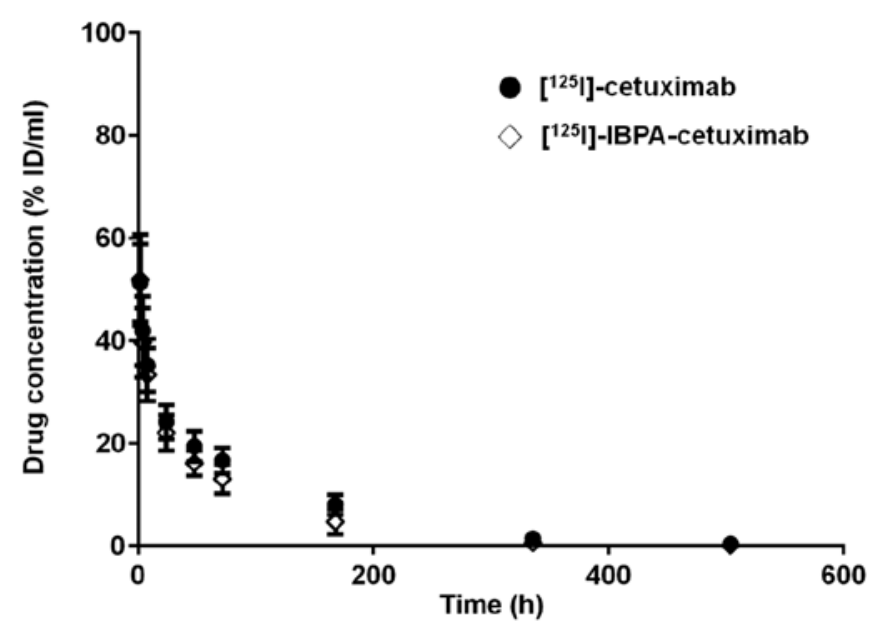

Figure 7. Average plasma radioactivity concentration vs. time curve obtained in nude mice bearing LS174T xenografts after i.v. injection of $\left[{ }^{125} \mathrm{I}\right]$-cetuximab $(\bullet$, dose $24.4 \mu \mathrm{g} / 20.2 \mu \mathrm{Ci} /$ each, $\mathrm{n}=5)$ and $\left.{ }^{[25} \mathrm{I}\right]$-IBPA-cetuximab $(\diamond$, dose $23.6 \mu \mathrm{g} / 22.4 \mu \mathrm{Ci} /$ each, $\mathrm{n}=5)$. Values are presented as mean $\% \mathrm{ID} / \mathrm{ml} \pm \mathrm{SD}$. $\% \mathrm{ID} / \mathrm{ml}$, the percent injected dose per a milliliter of plasma.

model analysis. The clearance aspects of [ $\left.{ }^{125} \mathrm{I}\right]$-cetuximab and $\left[{ }^{125} \mathrm{I}\right]$-IBPA-cetuximab in plasma were similar. The plasma pharmacokinetic parameters are shown in Table III. The mean terminal half-life of $\left[{ }^{125} \mathrm{I}\right]$-cetuximab and $\left[{ }^{125} \mathrm{I}\right]$-IBPAcetuximab were $91.0 \pm 8.0$ and $73.8 \pm 4.8 \mathrm{~h}$, respectively. The half-life of $\left[{ }^{125} \mathrm{I}\right]$-IBPA-cetuximab in plasma was shorter than that of $\left[{ }^{125} \mathrm{I}\right]$-cetuximab in nude mice bearing subcutaneous LS174T tumor xenografts $(\mathrm{P}<0.005)$. The other pharmacokinetic parameters were not significantly different.

\section{Discussion}

Radioiodinated $\mathrm{mAbs}$ are a promising approach for the diagnosis and treatment of cancer $(16,17)$. There is some concern about their in vivo catabolism and deiodination. Considerable interest has developed concerning the development of a new radioiodination linker that is metabolically more stable in vivo. Radioiodination linkers conjugated to Abs have been reported (18-21). These new radioimmunoconjugates have significantly lower radioiodine uptake in the thyroid in comparison with directly radioiodinated $\mathrm{mAbs}$.

In this study, the superiority of the residualizing labeled mAb (N-(4-isothiocyanatobenzyl)-2-(3-(tributylstannyl) phenyl) acetamide (IBPA; patent no. 10-1550399KR) over directly radioiodinated $\mathrm{Ab}$ was demonstrated in vitro and in vivo. IBPA was evaluated using cetuximab in LS174T tumor xenografts that overexpressed epidermal growth factor receptor.

The yield of residualizing radioiodine labeled $\mathrm{mAb}$ was improved in comparison to the $\mathrm{mAb}$ labeled in a different manner (18). [ ${ }^{125}$ I]-IBPA-cetuximab was very stable in human and mouse sera, with no deiodination evident (Fig. 2). Radioactivity was still bound to the Ab. The major factor for the deiodination of proteins is the structural similarity between these iodophenyl groups and thyroid hormones, compounds that have diversely specific deiodinases. A meta-substituted aryl halide was selected to avoid the loss of iodide due to nucleophilic substitution, as discussed previously (22).

In vitro, the immunoreactive fraction of $\left[{ }^{125} \mathrm{I}\right]$-IBPAcetuximab was about twice as high as $\left[{ }^{125} \mathrm{I}\right]$-cetuximab using the chloramine-T method. Also, the internalization percentage of $\left[{ }^{125} \mathrm{I}\right]-$ IBPA-cetuximab was higher than $\left[{ }^{125} \mathrm{I}\right]$-cetuximab (Table I). Tyrosine residues abound in the complementarity determining region (CDR) of antibodies (23). Iodination of tyrosine can considerably decrease or destroy the antigenbinding capability of mAbs (24). On the other hand, lysines are present in CDRs to a much lesser extent (25) and conjugation labeling provides better immunoreactivity of the conjugate and tumor accumulation.

The intracellular degradation of radioiodinated mAbs appears to be rapid and to lead to the excretion of radiocatabolites. In the case of directly labeled mAbs, the major 
radiocatabolite is monoiodotyrosine, which undergoes deiodination during circulation in the body. Uptake of radioiodine in the thyroid and stomach probably reflects the fact that deiodination plays an important role in the catabolism of radioiodinated $m A b s$ (26). In paired-label tissue distribution measurements, the use of the IBPA method for the radioiodination of cetuximab reduced the thyroid uptake of radioiodine by $\sim 8$-fold $(\mathrm{P}<0.005)$ and decreased activity levels in the stomach by 2 -fold $(\mathrm{P}<0.000005)$ at $48 \mathrm{~h}$ (Fig. 5). Also the thyroid uptake of $\left[{ }^{125} \mathrm{I}\right]$-cetuximab $(1.79 \pm 0.46)$ was $\sim 17$-fold higher than $\left[{ }^{125} \mathrm{I}\right]-\mathrm{IBPA}$-cetuximab $(0.11 \pm 0.02)$ in nude mice $(\mathrm{P}<0.0005$; data not shown). Furthermore, the thyroid uptake of $\left[{ }^{125} \mathrm{I}\right]$-IBPA-cetuximab was $\sim 3$-fold lower than the thyroid uptake of $\left[{ }^{125} \mathrm{I}\right]$-cetuximab at $48 \mathrm{~h}(\mathrm{P}<0.006)$ in planar imaging (Fig. 4). In the biodistribution and planar imaging studies, the tumor uptake of $\left[{ }^{125} \mathrm{I}\right]$-IBPA-cetuximab was $\sim 2$-fold higher than the tumor uptake for $\left[{ }^{125} \mathrm{I}\right]$-cetuximab at $48 \mathrm{~h}(\mathrm{P}<0.0006)$. Clearly, the targeting efficiency of radioiodinate $\mathrm{mAb}$ using IBPA to tumor was improved compared to previously reported data (18). The tumor/normal tissue ratio was also significantly higher in the IBPA method than the chloramine-T method (Table II). This may be due to a combination of improvements in inertness to deiodination in vivo, rate of clearance of labeled catabolites, and antibody affinity.

In order to investigate the effects of IBPA in systemic circulation, plasma radioactivity concentration-time profiles of $\left[{ }^{125} \mathrm{I}\right]$-IBPA-cetuximab and $\left[{ }^{125} \mathrm{I}\right]$-cetuximab were determined. Alternatively, the $\left[{ }^{125} \mathrm{I}\right]$-IBPA-cetuximab may possess a shorter biologic half-life than $\left[{ }^{125} \mathrm{I}\right]$-cetuximab $(\mathrm{P}<0.005)$ (Table III). In biodistribution results, $\left[{ }^{125} \mathrm{I}\right]$-IBPA-cetuximab showed a lower blood concentration after injection than $\left[{ }^{125} \mathrm{I}\right]$-cetuximab at $48 \mathrm{~h}$ (Fig. 5). These results suggest that $\left[{ }^{125} \mathrm{I}\right]$-IBPA-cetuximab clears from the body more rapidly than $\left[{ }^{125} \mathrm{I}\right]$-cetuximab.

This study demonstrates that use of IBPA could induce favorable pharmacokinetic characteristics, such as rapid clearance from systemic circulation. The half-life of [ $\left.{ }^{125} \mathrm{I}\right]$-cetuximab $(115.1 \pm 31.6 \mathrm{~h})$ in plasma was significantly shorter than $\left[{ }^{125} \mathrm{I}\right]-\mathrm{IBPA}$-cetuximab $(177.7 \pm 13.6 \mathrm{~h})$ in nude mice $(\mathrm{P}<0.005$; data not shown). [ $\left.{ }^{125} \mathrm{I}\right]-$ IBPA-cetuximab disappeared more quickly in the blood than $\left[{ }^{125} \mathrm{I}\right]$-cetuximab in tumor xenografts in contrast to the normal nude mice. [ $\left.{ }^{125} \mathrm{I}\right]$-IBPA-cetuximab is specific to the bound tumor site more than $\left[{ }^{125} \mathrm{I}\right]$-cetuximab and can rapidly disappears in normal tissues. Degradation of proteins labeled using the IBPA method should result in the production of iodide and monoiodophenolic acid as labeled catabolites. These findings further support the previously reported results of significantly lower uptake of radioiodine in the thyroid when monoiodobenzoic acid was injected into mice, and that whole body clearance of radioiodine was considerably faster than that of iodide (13).

All the results indicate that the $\left[{ }^{125} \mathrm{I}\right]-\mathrm{IBPA}$-cetuximab is very stable in vivo. [ $\left.{ }^{125} \mathrm{I}\right]$-IBPA-cetuximab has improved tumor targeting and retention. IBPA is a promising bi-functional linker for radioiodination of proteins for in vivo applications including radioimmuno -diagnosis and -therapy.

\section{Acknowledgements}

This study was supported by National R\&D Program through the National Research Foundation of Korea (NRF) funded by the Ministry of Science, ICT and Future Planning (no. 1711026888).

\section{References}

1. Tolmachev V, Orlova A and Lundqvist H: Approaches to improve cellular retention of radiohalogen labels delivered by internalising tumour-targeting proteins and peptides. Curr Med Chem 10: 2447-2460, 2003.

2. Heppeler A, Froidevaux S, Eberle AN and Maecke HR: Receptor targeting for tumor localisation and therapy with radiopeptides. Curr Med Chem 7: 971-994, 2000.

3. Stein R, Govindan SV, Hayes M, Griffiths GL, Hansen HJ, Horak ID and Goldenberg DM: Advantage of a residualizing iodine radiolabel in the therapy of a colon cancer xenograft targeted with an anticarcinoembryonic antigen monoclonal antibody. Clin Cancer Res 11: 2727-2734, 2005.

4. Milenic DE, Brady ED and Brechbiel MW: Antibody-targeted radiation cancer therapy. Nat Rev Drug Discov 3: 488-499, 2004.

5. Pruszynski M, Koumarianou E, Vaidyanathan G, Revets $H$, Devoogdt N, Lahoutte T, Lyerly HK and Zalutsky MR: Improved tumor targeting of anti-HER2 nanobody through $\mathrm{N}$-succinimidyl 4-guanidinomethyl-3-iodobenzoate radiolabeling. J Nucl Med 55: 650-656, 2014.

6. Hadley SW and Wilbur DS: Evaluation of iodovinyl antibody conjugates: Comparison with a p-iodobenzoyl conjugate and direct radioiodination. Bioconjug Chem 1: 154-161, 1990.

7. Bale WF and Spar IL: Studies directed toward the use of antibodies as carriers of radioactivity for therapy. Adv Biol Med Phys 5: 285-356, 1957.

8. Wilbur DS: Radiohalogenation of proteins: An overview of radionuclides, labeling methods, and reagents for conjugate labeling. Bioconjug Chem 3: 433-470, 1992.

9. Kaminski MS, Zasadny KR, Francis IR, Milik AW, Ross CW Moon SD, Crawford SM, Burgess JM, Petry NA, Butchko GM, et al: Radioimmunotherapy of B-cell lymphoma with $\left[{ }^{131} \mathrm{I}\right]$ anti-B1 (anti-CD20) antibody. N Engl J Med 329: 459-465, 1993.

10. Press OW, Shan D, Howell-Clark J, Eary J, Appelbaum FR, Matthews D, King DJ, Haines AM, Hamann P, Hinman L, et al: Comparative metabolism and retention of iodine-125, yttrium- 90 , and indium-111 radioimmunoconjugates by cancer cells. Cancer Res 56: 2123-2129, 1996.

11. Steiner M and Neri D: Antibody-radionuclide conjugates for cancer therapy: Historical considerations and new trends. Clin Cancer Res 17: 6406-6416, 2011.

12. Zalutsky MR and Narula AS: A method for the radiohalogenation of proteins resulting in decreased thyroid uptake of radioiodine. Int J Rad Appl Instrum [A] 38: 1051-1055, 1987.

13. Garg PK, Alston KL and Zalutsky MR: Catabolism of radioiodinated murine monoclonal antibody $\mathrm{F}\left(\mathrm{ab}^{\prime}\right) 2$ fragment labeled using N-succinimidyl 3-iodobenzoate and Iodogen methods. Bioconjug Chem 6: 493-501, 1995.

14. Mattes MJ, Griffiths GL, Diril H, Goldenberg DM, Ong GL and Shih LB: Processing of antibody-radioisotope conjugates after binding to the surface of tumor cells. Cancer 73 (Suppl): 787-793, 1994.

15. Lindmo T, Boven E, Cuttitta F, Fedorko J and Bunn PA Jr: Determination of the immunoreactive fraction of radiolabeled monoclonal antibodies by linear extrapolation to binding at infinite antigen excess. J Immunol Methods 72: 77-89, 1984.

16. Kraeber-Bodéré $F$, Bodet-Milin $C$, Rousseau $C$, Eugène $T$, Pallardy A, Frampas E, Carlier T, Ferrer L, Gaschet J, Davodeau F, et al: Radioimmunoconjugates for the treatment of cancer. Semin Oncol 41: 613-622, 2014.

17. Boswell CA, Marik J, Elowson MJ, Reyes NA, Ulufatu S, Bumbaca D, Yip V, Mundo EE, Majidy N, Van Hoy M, et al: Enhanced tumor retention of a radiohalogen label for sitespecific modification of antibodies. J Med Chem 56: 9418-9426, 2013.

18. Ram S and Buchsbaum DJ: Radioiodination of monoclonal antibodies D612 and 17-1A with 3-iodophenylisothiocyanate and their biodistribution in tumor-bearing nude mice. Cancer 73 (Suppl): 808-815, 1994

19. Srivastava PC, Buchsbaum DJ, Allred JF, Brubaker PG, Hanna DE and Spicker JK: A new conjugating agent for radioiodination of proteins: Low in vivo deiodination of a radiolabeled antibody in a tumor model. Biotechniques 8: 536-545, 1990. 
20. Khawli LA, Chen FM, Alauddin MM and Epstein AL: Radioiodinated monoclonal antibody conjugates: Synthesis and comparative evaluation. Antibody Immunoconjugates Radiopharm 4: 163-182, 1991.

21. Garg S, Garg PK and Zalutsky MR: N-succinimidyl 5-(trialkylstannyl)-3-pyridinecarboxylates: A new class of reagents for protein radioiodination. Bioconjug Chem 2: 50-56, 1991.

22. Carey FA, Sundberg RJ: Advanced organic chemistry. Plenum Press B: 400, 1983.

23. Nikula TK, Bocchia M, Curcio MJ, Sgouros G, Ma Y, Finn RD and Scheinberg DA: Impact of the high tyrosine fraction in complementarity determining regions: Measured and predicted effects of radioiodination on IgG immunoreactivity. Mol Immunol 32: 865-872, 1995.
24. Olafsen T, Bruland OS, Zalutsky MR and Sandlie I: Abundant tyrosine residues in the antigen binding site in anti-osteosarcoma monoclonal antibodies TP-1 and TP-3: Application to radiolabeling. Acta Oncol 35: 297-301, 1996.

25. Olafsen T, Bruland OS, Zalutsky MR and Sandlie I: Cloning and sequencing of $\mathrm{V}$ genes from anti-osteosarcoma monoclonal antibodies TP-1 and TP-3: Location of lysine residues and implications for radiolabeling. Nucl Med Biol 22: 765-771, 1995.

26. Press OW, Howell-Clark J, Anderson S and Bernstein I: Retention of B-cell-specific monoclonal antibodies by human lymphoma cells. Blood 83: 1390-1397, 1994. 